\title{
International Labour Standards and National Labour Laws in Pakistan
}

\section{S. Nazre Hyder*}

\section{Introduction}

The genesis of setting International Labour Standards lies in the idea that the issues related to labour and social conditions are not merely matters of state concern. The objective of establishing the International Labour Organisation in 1919 was to undertake joint international action to improve labour conditions world wide along with achieving several inter-related motives. The preamble and the first Article of the ILO's Constitution gives expression to these ideas by the following statement:

Whereas universal and lasting peace can be established only if it is based upon social justice; and whereas conditions of labour exist involving such injustice, hardship and privation to large numbers of people as to produce unrest so great that the peace and harmony of the world are imperiled; and an improvement of those conditions is urgently required....”. Furthermore, Article I of the Constitution says that "moved by the sentiments of justice and humanity as well as by the desire to secure the permanent peace of the World and with a view to attaining the objectives set forth in the Preamble", the founder countries agree to establish a permanent organisation to achieve its goal mainly through framing international instruments to these effects.

International Labour Standards that are evolved through adopting the ILO's Conventions serve as guidelines for legislating labour laws by member states and on being ratified by them, these assume the force of international law on them. To date 176 Conventions have been adopted with varying rates of ratifications by the present 174 member states. The objective of the paper is to examine as to what extent the labour laws, rules and regulations in Pakistan are in consonance with the International Labour Standards. Since any comprehensive evaluation in this regard may not be

\footnotetext{
* The author is currently Director, Pakistan Manpower Institute, Ministry of Labour, Manpower \& Overseas Pakistan. The views expressed in the paper in no way reflect the opinion of the organisation he is serving.
} 
possible within the limits of a relatively short article ${ }^{1}$, the following analysis is almost "impressionistic" and lays no claim to being exhaustive.

\section{Impact of International Labour Standards and Recommendations on National Labour Laws - A Review of Evidence}

The labour laws, rules and regulations which existed at the time of the partition of the Indo-Pak sub-continent in 1947 were adopted by the nascent state of Pakistan. Realising the significance of promoting a healthy industrial atmosphere, it also joined the ILO shortly after its independence and the Government pledged to honour all the commitments made with them by the Government of British India. The comprehensive legal framework which Pakistan inherited was largely based on 14 Conventions of the ILO which were ratified by British India during 1921-47 (Annexure-I).

Industrial relations in Pakistan in the early days were mainly governed by rules and regulations existing at the time of independence and the laws provided under the Industrial Relations Ordinance, 1969 [Ministry of Labour and Manpower, 1978] which, to a considerable extent, were based on $14 \mathrm{ILO}$ Conventions ratified by British India. However, to further improve the legal framework for protecting the rights of the workers and employers to create a better industrial climate in the country, the labour laws, rules and regulations are revised and modified in Pakistan, from time to time, according to the changing needs, standards and principles set out by the ILO. In order to achieve these objectives, Pakistan, as an active member of ILO ratified an additional 17 Conventions of the ILO (Annexure-I) to improve labour standards in the country through promoting tripartism, improving standards of social justice, maximising protection to workers and extending the coverage of the labour force. Moreover, the Government also adopted, from time to time, 19 ILO Recommendations (Annexure-II) to this effect.

The subjects of Conventions, ratified by Pakistan, broadly cover the areas of hours of work; freedom of association; collective bargaining; prohibition of employment of women and young persons during night hours; medical examination of young persons at sea; workmen's compensation for injuries as a result of accidents; abolition of fee charging employment policies; discrimination on the basis of sex in employment and

\footnotetext{
${ }^{1}$ In the case of Pakistan, the international instruments even if not ratified are found, in a number of cases, to be the source of reference for the harmonisation of measures taken at the national level; for example concerning employees cost of living relief; workers' children education and institutional arrangements for the settlement of industrial disputes account should also be taken of the influence of a number of ILO's Recommendations; for example the provisions of the Termination of Employment Recommendation, 1963 (No. 119) are clearly reflected in the labour legislation of the country but it has not been adopted.
} 
occupation; social security; tripartite consultation, vocational rehabilitation; abolition of forced labour, etc.

As regards the Recommendations of ILO adopted by Pakistan, they deal with areas such as vocational training of adults; collective agreements; voluntary conciliation and arbitration; cooperation at the level of undertaking; minimum age for entry into employment in coal mines; protection of workers' health; holiday with pay; employment and occupational discrimination; communication within the undertakings; examination of grievances and a host of other welfare measures. The developments, which have taken place in the labour laws of the country and those which are in the process, are aimed at establishing the charter for harmonious industrial relations and to improve the socio-economic conditions of labour, based on the principles laid down in the relevant ILO instruments.

\section{Recent Developments in Labour Laws in Pakistan in Relation to International Labour Standards}

Five ILO Conventions numbering 29, 87, 98, $105 \& 111$; out of the seven "Core Conventions" i.e., 29, 87, 98, 105, 111, 118 and 159 (AnnexureI) ratified by Pakistan and 16 Recommendations out of 19 accepted, have a human rights dimension as well as fundamental framework conditions for the exercise of labour rights, known as internationally recognised workers' rights. Many of them are found already institutionalised through various labour laws of the country which provided a wide range of social protection by the government and mainly "so to say" by employers. As stated earlier, these included compensation to the workers for industrial accidents; education of children of workers; maternity benefits; medical care; pension and provident fund schemes; right of association; collective bargaining; institutional framework for the settlement of industrial disputes etc.

In recent years, however, there is a growing awareness of the need to provide social protection to the weaker sections of society such as disabled persons, bonded labour and children, besides specific measures adopted to protect a certain level of income of unskilled workers in industrial and commercial organisations. Some of the recent measures taken by the Government based on international labour standards as 1aid down by the ILO are described as under:

a) Child Labour: The exploitation of child labour is one of the disturbing aspects of the international scene. Although the incidence of child labour in the country is much lower than that in many countries of even South Asia, the abolition of child labour and more generally the protection of children and young persons against work of a character or conditions unsuitable to 
their age has always been a serious government concern [Hyder, 1997b]. The Constitution of the country itself provided that all forms of forced labour and traffic in human beings are illegal and children below the age of 14 years are prohibited to work in any factory or mine or any hazardous activity.

A number of legislative measures were also adopted by the government to this end. The first step was taken by adopting the Minimum Age (Industry) Convention, 1919 ratified by British India which fixed the minimum age for admission of children to industrial employment at 14 years. As a consequence of this ratification, the Government enacted a number of laws to regulate children's employment in several sectors. These laws included the Mines Act, 1923; the Children (Pledging of Labour) Act, $1933^{2}$; the Factories Act, 1934; the Employment of Children Act, 1938 and Establishment Ordinance, 1969.

More recently in the wake of the UN Convention on the Rights of Children, the Government of Pakistan has set up a National Commission on Child Welfare and Development to look after the rights of children. As a consequence, the Employment of Children Act, 1991 [Ministry of Labour, Manpower and Overseas Pakistanis, 1991] has also been enacted which ensured the protection of children from exploitation and provided for their safety and health. It lays down that no child below the age of fourteen years shall be engaged in any factory or mine or in any hazardous employment and also specifies these occupations. The employment of a child below the age of 14 years is a cognisable offence under the Act and is punishable with imprisonment and fine. The Act also helped in removing the anomaly resulting from different age limits prescribed in different laws framed from time to time as stated above [Kemal, 1994].

A Memorandum of Understanding has also been signed in 1994 between the Government of Pakistan and the International Labour Office recognising the rights of children to be protected from economic exploitation and from performing any work that is likely to be hazardous or to interfere with the child's education, or to be harmful to the child's health or physical, mental and spiritual, moral or social development. It has also been re-affirmed that national efforts will be aimed at the eventual elimination of child labour. Consequently, Pakistan also joined the International Programme of Elimination of Child Labour in 1994 to achieve their goal [Hyder, 1997b].

2 Although the Forced Labour Convention, 1930 was ratified in 1957 by the Government, the law to this effect was enacted earlier. 
b) Bonded Labour: Realising the significance of abolition of the bonded labour system with a view to preventing the economic and physical exploitation of various oppressed sections of the labour class, the Government has enacted the Bonded Labour System (Abolition) Act, 1992 [Ministry of Labour, Manpower and Overseas Pakistanis, 1993]. At the commencement of this Act, the bonded labour system stands abolished and every bonded labourer has been freed and discharged from any obligation to render any bonded labour. Moreover, every obligation of a bonded labourer to repay any bonded debt has been extinguished and the possession of any property belonging to a bonded labourer or a member of his family, which was taken forcibly by any creditor for the recovery of any bonded debt, has been restored after commencement of the Act.

The Act also provided that whosoever compels any person to render any bonded labour shall be punishable with imprisonment for a term which shall not be less than two years nor more than five years, or with fine which shall not be less than fifty thousand rupees or with both. Similarly, if any person enforces any custom, tradition, contract or other instrument, by virtue of which any person or any member of his family is required to render any service under the bonded labour system, shall be punishable with imprisonment and fine.

c) Minimum Wages: Partly because of the global move for equitable wages for workers and partly to cater for the escalating cost of living, the Government improved the existing legislation by enacting the Minimum Wage for Unskilled Workers (Amendment) Act, 1993 [Ministry of Labour, Manpower \& Overseas Pakistanis, 1993]. It provided a hefty increase in the minimum wage to unskilled workers throughout the country. In addition to this, a cost of living allowance at the rate of Rs. 100 per month was allowed for workers with effect from 1st September, 1993 and another cost of living allowance at the rate of Rs. 50 per month was given w.e.f. 1st April, 1996 under the Employees Cost of Living (Relief) Act, 1973. Further, an ad-hoc relief of Rs. 300 per month was granted w.e.f. 1-3-1997 under the said Act. With this increase, the minimum wage of an un-skilled worker rose to Rs. 1950 per month; while in practice the wages paid to the un-skilled workers are found to be quite high in many cases.

The Government has now set up a National Minimum Wage Council, with tripartite composition to achieve uniformity in minimum wages for different categories of workers. It will undertake a periodic review of minimum wages for unskilled workers to make recommendations to the Government to enable it to fulfill its pledge to ameliorate the lot of workers. 
d) Rehabilitation of Disabled Persons: Another significant development in recent years is concerning the ratification of an ILO Convention, namely Vocational Rehabilitation and Employment (Disabled Persons) Convention, 1983 by the Government of Pakistan in October, 1994. It calls for the need to ensure equality of opportunity and treatment to all categories of disabled persons, in both rural and urban areas, for employment and their integration into the community. It further calls for following the principle of equality of opportunities and treatment for men and women while providing vocational rehabilitation and employment assistance to disabled persons, as well as measures to promote employment opportunities for them which conform to the employment and salary standards applicable to workers generally.

Moreover, in its National Social Welfare Policy also, as announced by the Government of Pakistan in 1994, special attention has been paid to disabled persons and the aforementioned Convention of ILO and Disabled Persons (Employment and Rehabilitation) Ordinance, 1981 have been made the basis for launching future government efforts to create special facilities for their education, training and rehabilitation through the provision of equal opportunities of employment to them [Government of Pakistan, 1994].

\section{Concluding Remarks}

It may be noted that despite a distinct employment feature of the country characterised by a large proportion of employed labour force in agriculture and the informal sector, a substantial size of the work force is found engaged in the organised sector of the economy. It is estimated that at least $12-14$ per cent of the labour force in Pakistan falls into the formal or organised sector which is protected by fairly comprehensive labour laws covering collective bargaining, tripartism as consultative mechanism, industrial disputes, unfair dismissal, trade union rights, working conditions, employees old age benefits, workmen's compensation, health and safety etc. Restrictions on the employment of children and young persons, restrictions on night work for women, maternity benefits and social security are all covered by these laws. These facts reveal that the legal labour system in Pakistan has followed, to a great extent, the International Labour Standards (ILO Conventions and Recommendations) in shaping its industrial relations framework for the country to protect the social and economic rights of the workers and to establish a congenial industrial atmosphere.

Moreover, the new Labour Policy which is in the offing, envisages a number of dynamic provisions such as the establishment of a Commission to consolidate, simplify and rationalise labour laws, National Safety and Health Council, National Productivity Council and extension in scope and benefits under a scheme such as old age benefits for the workers and workers' 
children education schemes. Also being considered is to provide protection to the rights of agricultural workers and extend welfare amenities for mine workers at par with other workers.

The Government believes that in the realisation of increased competitiveness, growth and employment in a globalised economy, a highly educated and skilled labour force has a critical and prominent role to play. Measures are being taken to expand the base of vocational and skilled training in new and multiple trades to meet the challenges of new technology and to fully benefit from developments in the field of communication and information technology.

However, an important issue that has emerged during the recent past is whether or not a social clause should be included in Multilateral Trade Agreements under the World Trade Organisation to ensure compliance with labour standards. The pressure in this regard is considered by most people in developing countries as a measure not oriented to supporting long-term structural reforms with pro-poor perspective, showing concern for human rights but to protect the interest of their own workers and the economy.

It may be observed that like the provision of a social clause, environmental standards and human rights, linking labour standards with trade under W'TO Agreements represents an unfair non-trade related barrier. In fact, it is considered as an effort to disallow a level playing field in trade with distinct disadvantage to Pakistan as for many other countries of the South. This kind of tainted approach at the international level, instead of solving the issues, is likely to aggravate the problems in these countries [Hyder, 1997b \& 1997a].

Moreover, it is felt that the ILO, being an effective organisation at the international level to set and deal with international labour standards, is the most appropriate body to look into this aspect which has already contributed substantially in this field. Instead of linking labour standards with trade, the most appropriate approach will rather be to effectively implement ILO Conventions which should be facilitated by the ILO in terms of extending technical cooperation, provision of resources and realistic setting of labour standards. These standards should be framed taking into account the diversity in the social, economic and cultural scenario of the countries in different parts of the world to cater to their varying circumstances. 
134 The Lahore Journal of Economics, Vol.5, No.2

Annexure-I

List of ILO Conventions Ratified by Pakistan

\begin{tabular}{|c|c|c|c|}
\hline S.No. & No. of Convention & Title & Date of Ratification \\
\hline 1 & 2 & 3 & 4 \\
\hline 01 . & No. 1 & $\begin{array}{l}\text { Hours of work (Industry) } \\
\text { Convention, } 1919\end{array}$ & $14-07-1921$ \\
\hline 02 . & No. 4 & $\begin{array}{l}\text { Night work (Women) } \\
\text { Convention, } 1919 .\end{array}$ & 14-07-1921 \\
\hline 03. & No. 6 & $\begin{array}{l}\text { Night work of young persons } \\
\text { (industry) Convention, } 1919 .\end{array}$ & 14-07-1921 \\
\hline 04. & No. 11 & $\begin{array}{l}\text { Right of Association } \\
\text { (Agriculture) } \\
\text { Convention, } 1921 .\end{array}$ & $11-05-1923$ \\
\hline 05 . & No. 14 & $\begin{array}{l}\text { Weekly Rest (Industry) } \\
\text { Convention, } 1921 .\end{array}$ & $11-05-1923$ \\
\hline 06. & No. 15 & $\begin{array}{l}\text { Minimum Age (Trimmers \& } \\
\text { Stokers) Convention } 1921 .\end{array}$ & $20-11-1922$ \\
\hline 07. & No. 16 & $\begin{array}{l}\text { Medical Examination of } \\
\text { young persons (Sea) } \\
\text { Convention, } 1921 .\end{array}$ & $20-11-1922$ \\
\hline 08 & No. 18 & $\begin{array}{l}\text { Workmen's Compensation } \\
\text { (Occupational Diseases) } \\
\text { Convention, } 1925 .\end{array}$ & 30-09-1927 \\
\hline 09 . & No. 19 & $\begin{array}{l}\text { Equality of Treatment } \\
\text { (Accident Compensation) } \\
\text { Convention, } 1925 .\end{array}$ & 30-09-1927 \\
\hline 10. & No. 21 & $\begin{array}{l}\text { Inspection of Emigrants } \\
\text { Convention, } 1926 .\end{array}$ & $31-10-1932$ \\
\hline 11. & No. 22 & $\begin{array}{l}\text { Seamen's Articles of Agree- } \\
\text { ment Convention, } 1926 .\end{array}$ & $31-10-1932$ \\
\hline 12. & No. 27 & $\begin{array}{l}\text { Marking of Weight (Packages } \\
\text { Transported by Vessels) } \\
\text { Convention, } 1929 .\end{array}$ & 07-09-1931 \\
\hline 13. & No. 29 & $\begin{array}{l}\text { Forced Labour Convention, } \\
1930\end{array}$ & $23-12-1957$ \\
\hline 14. & No. 32 & $\begin{array}{l}\text { Protection against Accidents } \\
\text { (Dockers) Convention } \\
\text { (Revised), } 1932 .\end{array}$ & $10-02-1947$ \\
\hline
\end{tabular}


15. No. 45 Underground work (Women) 25-03-1938

Convention, 1935.

16. No. 59 Minimum Age (Industry) 26-05-1955

Convention (Revised), 1937.

$25-03-1948$

Convention, 1946.

18. No. $81 \quad$ Labour Inspection

10-10-1953

Convention, 1947.

19. No. $87 \quad$ Freedom of Association \& 14-02-1951

Protection of the Right to organise, Convention, 1948.

20. No. $89 \quad$ Night Work (Women)

14-02-1951

Convention (Revised), 1948.

21. No. 90 Night work of young persons 14-02-1951

(Industry), Convention

(Revised), 1948.

22. No. 96 Free-Charging Employment 26-05-1952

(Revised), 1949.

23. No. 98 Right to organise and

Collective Bargaining

Convention, 1949.

24. No. 105 Abolition of forced Labour 15-02-1960

Convention, 1957.

25. No. 106 Weekly Rest (Commerce and 15-02-1960

Offices) Convention, 1957.

26. No. 107 Indigenous and Tribal 15-02-1960

Populations Convention, 1957.

27. No. 111 Discrimination (Employment \& 24-01-1961

Occupation) Convention, 1958.

28. No. 116 Final Articles Revision 17-11-1967

Convention, 1961.

29. No. 118 Equality of Treatment (Social 27-03-1969

Security) Convention, 1962.

30. No. 144 Tripartite Consultations 25-10-1994

(International Labour

Standards) Convention, 1976.

31. No. 159 Vocational Rehabilitation and 25-10-1994

Employment (Disabled

Persons) Convention, 1983. 
136 The Lahore Journal of Economics, Vol.5, No.2

Annexure-II

List of ILO Recommendations accepted by Pakistan since Independence (i.e. after August, 1947)

\begin{tabular}{|c|c|c|c|c|}
\hline $\begin{array}{l}\text { Sr. } \\
\text { No. }\end{array}$ & $\begin{array}{l}\text { Number of } \\
\text { Recommen- } \\
\text { dations }\end{array}$ & $\begin{array}{c}\text { Name of the } \\
\text { Recommendations }\end{array}$ & $\begin{array}{c}\text { Date of } \\
\text { acceptance by } \\
\text { Pakistan }\end{array}$ & Remarks \\
\hline 1 & 2 & 3 & 4 & 5 \\
\hline 01. & No. 88 & $\begin{array}{l}\text { Vocational Training } \\
\text { (Adults) Recommen- } \\
\text { dation } 1950 .\end{array}$ & 20-10-1953 & $\begin{array}{l}\text { Accepted with the } \\
\text { exception of its } \\
\text { paragraphs } 5(4) \text { (b) } \\
17: 19: 26: 27: 28: 29: \\
30: 31: 32: 33: \& 34 \text {. }\end{array}$ \\
\hline
\end{tabular}

02. No. 91 Collective Agreement

Recommendation, 1951

03. No. 92 Voluntary Conciliation

and Arbitration

Recommendation, 1951.

04. No. 94 Cooperation at the 28-08-1954

Level of the

Undertaking

Recommendation, 1952

05. No. 96 Minimum Age (Coal 20-05-1957

Mines) Recommen-

dation, 1953.

06. No. 97 Protection of Workers' 20-05-1997 Accepted with the Health Recommen- $\quad$ exception of its dation, 1953.

paragraphs, (2)(1):

3(1)(a)(b), (c)(d),3(3)

4(1) (a),(b), \& (c),

5,6 \& 13. Besides

this it has been

specified by the

Govt. of Pakistan,

that the accepted

provision of the

Recommendation, in their application, would be limited to the places of 
07. No. 98 Holidays with Pay Recommendation, 1954.

08. No. 102 Welfare Facilities Recommendation, 1956. employment covered by the existing national laws and regulations only.

16-09-1959 Accepted with the exception of paragraph 14 of the Recommendation. The Govt. of Pakistan has further specified that the provision of the Recommendation, in their case, would be applicable to workers covered by the legislation on factories, shops and Commercial establishments.

20-07-1959 Accepted with the exception of its paragraphs 10:12: 29:30:31:32:33 and 34 .

09. No. 103 Weekly Rest (Commerce 29-12-1959 \& Offices) Recommendation, 1957.

Accepted with the exception of its paragraphs $1: 2$ : $4(1)$ and 7.

10. No. 105 Ships Medicine Chests 27-02-1960

Recommendation, 1958.

11. No. 106 Medical advice at Sea 27-02-1960 Recommendation, 1958.

12. No. 107 Seafarers Engagement (Foreign Vessels) Recommendation, 1958.

13. No. 108 Social Conditions and 27-02-1960 Safety (Seafarers)

Recommendation, 1958. 
138 The Lahore Journal of Economics, Vol.5, No.2

14. No. 111 Discrimination

(Employment \&

Occupation)

Recommendation, 1958.
30-12-1960 Accepted with the exception of its paragraph 8 .

15. No. 113 Consultation (Industrial 21-03-1962

and National Levels)

Recommendation, 1960.

16. No. 117 Vocational Training

Recommendation, 1962.

17. No. 129 Communications within the undertaking Recommendation, 1967.

18. No. 130 Examination of Grievances, Recommendation, 1967.

19. No. 168 Vocational 25-10-1994

Rehabilitation and Employment (Disabled Persons) Recommendation, 1983. 


\section{References}

Bhagwati, J.N., 1994 "Policy Perspectives and future directions : A View from Academia", International Labour Standards and Global Economic Integration: Proceedings of a Symposium, US Department of Labour, Washington, DC.

Government of Pakistan, 1994 National Social Welfare Policy, Social Welfare and Special Education Division, Islamabad.

Hensman, R., 1996 'Minimum Labour Standards and Trade Agreements An Overview of the Debate', Economic and Political Weekly, April 20 - 27 Issues New Delhi.

Hyder, S.N., 1997a "Globalisation of Economy - Pakistan at Crossroads", Pakistan Banker, January - June, 1997 Issue, The Bank of Punjab, Lahore.

Hyder, S.N., 1997b "Exploitation of Child Labour - Finding the Right Approach”, Pakistan Banker, July - December, 1997, The Bank of Punjab, Lahore.

Kemal, A.R., 1995 Child Labour in Pakistan - A Study Conducted for UNICEF and Pakistan Institute of Development Economics, UNICEF, Islamabad.

Lee, E., 1997 Globalisation and Labour Standards : A Review of Issues, International Labour Review, Vo1. 136, No. 2, ILO, Geneva.

Ministry of Labour, Manpower \& Overseas Pakistanis, 1978 The Pakistan Labour Code, Vo1. 1, Government of Pakistan, Labour Division, Islamabad.

Ministry of Labour, Manpower \& Overseas Pakistanis, 1991 Pakistan Labour Gazette, July, 1990 - June, 1991, Government of Pakistan, Labour Division, Islamabad.

Gazette, July, 1992 - June, 1993, Government of Pakistan, Labour Division, Islamabad. 
140 The Lahore Journal of Economics, Vol.5, No.2

Otting, A., 1993 'International Labour Standards : A Framework for Social Security', International Labour Review, Vo1. 132, No. 2, ILO, Geneva.

Pradhan, G., 1996 Social Clause in Multilateral Trade Agreements - A Paper submitted to South Asian Consultation on Social Clause in Multilateral Agreements, Staff College, Kathmandu, Nepal. 